\title{
The cultural mission of universities
}

\author{
Antonio Ariño Villarroya \\ UNIVERSITAT DE VALÈNCIA \\ antonio.arinoduv.es \\ Received: 03/07/2017 \\ Accepted: 04/09/2017
}

\begin{abstract}
Over the last two decades, there has been a wide debate about the so-called third mission of the University. Two discourses have occupied the proscenium: the transfer and innovation of knowledge and corporate social responsibility. In this article we postulate that both these ideas respond to approaches that do not fully take the history and status of universities as a public service into account. In contrast, we argue that the third mission, both in terms of history and in terms of the normative and pragmatic statutes, instead corresponds to culture.
\end{abstract}

Keywords: university mission, culture, corporate social responsibility, knowledge transfer, innovation.

Corresponding author: Antonio Ariño, Facultat de Ciències Socials Universitat de València. Av. dels Tarongers, 4b, 46021 Valencia. Suggested citation: Ariño, A. (2017), The cultural mission of universities. Debats. Journal on Culture, Power and Society, 2, 175-194. doi: http://dx.doi.org/10.28939/iam.debats-en.2017-14

You cannot discuss the ocean with a frog if it has never left its pond. You cannot discuss ice with a summer insect as it knows only its own season. You cannot discuss life with a sage if he is imprisoned by his doctrine.

(The Way of Chuang Tse, 4th century BC.)

\section{INTRODUCTION}

Here we discuss universities as historical institutions and as organisations that are undergoing change. Beyond their initial function originating in the Middle Ages, involving the transmission of the main branches of knowledge (theology, law, medicine, and the arts), other roles relating to the needs of different social structures (e.g., bourgeois, democratic or, knowledge society) have been incorporated and institutionalised into universities. This complex relationship between universities and society has been the dynamic force driving their ongoing transformation.
The first generation of universities revolved around the teaching function, i.e. 'preservation of the knowledge repository'. The second emerged with the incorporation of the scientific method and the research function. The third, a more complex generation, took shape recently through the institutionalisation of cultural functions (i.e. 'university extension') and of a sense of commitment to the society to which it belongs (including in terms of scientific development and innovation, social responsibility, and sustainability). By differentiating these three generations we do not 
intend to argue that the cultural dimension of universities did not exist before, but rather that it has been institutionalised in the later stages and that the social organisation called the University continues and will continue to change, though it may be difficult to predict how. ${ }^{1}$

Having established this interpretative framework, we will focus on the cultural function of universities in Spain, in its origins, its normative and organisational status, its current ambivalent situation and its possible future directions.

\section{A HISTORICAL PERSPECTIVE ON THE CULTURAL FUNCTION OF UNIVERSITIES}

\section{Background}

This year, 2017, the Universitat de València commemorates two events which, although not of great importance, have special symbolic relevance from a cultural perspective.

The first marks the date when the painting, the Virgen de la Sapiencia (Virgin of Wisdom), painted by Nicolás Falcó in 1516, was hung in the university chapel. Both the painting and the chapel on the university campus oblige us to adopt a realistic view of the origin of universities, even those, as is our case, promoted by the city rather than the monarchy or the church. The main mission of medieval universities was not the search for new knowledge, but rather, preservation of the dominant knowledge, which always had to be expressed in religious terms. In the 16th century, the Christian religion furnished and provided all

1 We adopt Wissema's idea of generations of universities (2009), although our historical vision diverges from it in terms of 19th and 20th century universities. Wissema (2009) distinguishes three generations according to the process whereby functions are incorporated: the second generation corresponds to the scientific or Humboldtian universities, whereas the third refers to the knowledge society and entrepreneurship universities (e.g., MIT, Stanford, Harvard, or Cambridge). the symbolic references with which the world was to be interpreted; indeed, theology reigned from the tower of knowledge.

Secondly, the Universitat de València was created following a model that was already present in other universities, the Saturday lectures or discussions-known as Sabatínas - can be seen as a remote antecedent of our conferences, discussion forums, and round-tables. All the professors were obliged to participate in these activities (failure to do so was penalised by fine), and citizens could attend these sessions in order to test the to level and dedication of the faculty to the studies funded by the city.

In the late 18th century, students were also required to perform this exercise. "Everyone-in accordance with the Faculty meeting of June 6, 1778-will give a lecture in the hall and attend the Academia pública (Public Academy) assigned to them, and defend their conclusions during the Sabatinas when requested to do so". Indeed, the expression 'Public Academy' harbours the seed of the concept of disclosing knowledge to society, which constitutes a fundamental component of the cultural mission of universities. These two elements, examples taken from the Universitat de València, were also present in many other universities and in all likelihood there are other manifestations and activities that also exemplify this facet.

\section{Cultural extension and enlightened intelligence}

The cultural function of universities was first institutionalised in the form of a university extension. The underlying idea, in other words, the mission to disseminate universal knowledge, is ancient. Among the precedents we can cite is the work undertaken by Sir Thomas Gresham or William Dill in the 17th century which aimed to promote popular education. But the term 'university extension' itself was coined in the last third of the 19th century, in the context of a growing cultural divide between university elites and the working classes in the first industrial and bourgeois revolution. In principle, awareness of this educational fracture did not question the 
access of minorities and elites to universities, but rather, the need to disseminate knowledge beyond the faculties and lecture halls.

Thus, this university initiative-to take knowledge from the lecture halls to the street-cannot be detached from the phenomenon known as the 'social question' and within the framework of the great accumulation of wealth that occurred at the end of the 19th century (the first Golden Age of Capitalism; Ariño and Romero, 2016). Within the context of that great social divergence, small sections of the faculty of professors became aware of the need to bridge these gaps and to promote an incipient democratisation of knowledge. Thus, in 1871, university extension was created by Cambridge University. This was soon followed by Oxford and other universities, and the first University Extension Journal was published. In the United States the Philadelphia American Society for Extension of University was founded in 1890 while in France this function was undertaken by the popular universities. ${ }^{2}$

In Spain, this movement officially began at the Universidad de Oviedo in 1898, on the initiative of Rafael Altamira, and was inspired by the one in Oxford (Altamira, 1949, p. 177). Its objective was very clear: "all social classes should enjoy the benefits of education" and all genders; indeed there was large female involvement right from the start (Altamira, 1949, p. 185). In the collection of texts by Rafael Altamira entitled Cuestiones Obreras (Workers' Issues) we can read a justification for this approach:

The starry sky is without doubt a magnificent thing, which almost everyone admires and finds appealing; however, it holds greater beauty and offers more enjoyment and entertainment for the enlightened spirit than for the ignorant. Just as the lighter the horizon the more our eyes see, so enlightened intelligence sees more, and can

2 This trend was very successful in France, indeed in 19021903 over 177,000 lectures were given for an audience of three and a half million (Altamira, 1949). envisage materially more things than the mind closed to culture as a whole. Truly, they do say that it is not the farmer-although he lives in the country-who most enjoys the landscape he sees around him, but rather the city dweller, who appreciates the lines and colours, the mounds and geographic accidents, the eyes of the soul are open and brimming with images (Altamira, 2012, p. 18).

Rafael Altamira believed every human being had the right to enlighten his gaze and promoting this idea was the obligation of what he called 'post-school institutions'. Like many who promoted university extension, he was influenced by the Institución Libre de Enseñanza (free teaching institution). Its path of action was clear: on the one hand, to promote the democratisation of knowledge, ingrained in the social movements of the time, and especially the workers' movement; and on the other, to defend the universal conception of knowledge, because anyone - even someone with a university education-is always "more than just their profession": the chemist also has human knowledge.

This idea came to fruition and spread from Oviedo to other Spanish universities, and retained certain validity until the mid-1920s. At the Universitat de València this movement can be traced to 1902, and took a foothold in Barcelona and Granada shortly thereafter.

\section{The scope of university extension}

In 1930, in the context of the protests against the law decreed on May 19, 1928 by Primo de Rivera, related to a somewhat authoritarian reform of universities, Ortega gave several lectures, at the behest of the Federación Universitaria Escolar (University School Federation), on the mission of universities. We should bear in mind both the historical context and the conference audiences. The former concerned the creation of student associations and demonstrations against the dictatorship while the latter made an extraordinarily modern proclamation of the centrality of University students (Ortega y Gasset, 2015 [1930]). These conferences addressed how the people attending lecture halls were to be trained and what universities should contribute to society. 
In parliament, Ortega attacked the reforms for being an 'imitation' of those instated in other countries (England or Germany) and the 'idealistic beguinage' that ignores the real uses of institutions. Ortega's opinion was categorical and clear: universities should be at the 'service of society' and must serve three functions, the first and foremost being the transmission of culture. This function, as we will see, is played out both inside (as universal training of educated people) and outside (as civic leadership).

Ortega goes straight to the point when he says that the "university means a privilege that is hardly justifiable and sustainable" because the workers are excluded. In this respect, university extension failed to achieve the 'universalisation of universities'. But, the most serious problem is not related to access, but in the inability to assume the inherent functions. At that time, two functions were an indisputable priority for Ortega: teaching intellectual professions and training researchers, although the latter has lacked steady implementation in Spain. Universities produce professionals, specialists, and scientists. However, although they may be very 'wise' or experts in their field, they may also be totally 'uncultured' or even 'uncouth' in regard to the system of ideas of their time. Ortega states:

To be successful in the jungle of life you have to be educated, you have to know its topography, its paths or 'methods'; i.e., you have to have an idea of the space and the time in which you live, your current culture. Nonetheless, that culture is received or invented. Only one daring enough to invent it alone, to do what has been done in thirty centuries of humanity, would have the right to deny the need for the University to deal primarily with teaching culture. Unfortunately, the only being that could oppose the foundations of my thesis seriously would be a madman.

Consequently, professionalism and scientism must be compensated with culture, encompassing the vital system of ideas of each epoch. "In the engineer is engineering, which is only one part and one dimension of the European man; but this, which is an integrum, is not found in the engineer part. And so it is in all other cases". Laying aside his vitalist philosophy and his idealisation of the origins of the University as an entity (Muñoz, 2007), Ortega's conclusion on its mission is clear: it encompasses three functions, which are (in this order) the transmission of culture, the teaching of professions, and the undertaking of scientific research.

What was Ortega's definition of culture? "A constituent dimension of human existence and an indispensable necessity of life". That said, one might suspect that Ortega shared an anthropological view of culture and entertained a purely descriptive concept: the way of life of a people. However, he reiterates that this constituent dimension is embodied in the system of living ideas necessary to live up to the epoch in which he lives. It is not, therefore, a question of a repertoire of ideas and beliefs, nor of knowledge as a whole, but of a selection of ideas, beliefs and knowledge that enables us to rigorously tackle the problems faced by society at a given time. Thus the importance of the qualifier current is manifest in five basic disciplines (physics, biology, history, philosophy, and sociology) because, through them, mankind manages to squeeze its existence into the requirements of its time. Thus, university culture allows the comprehensive education of professionals, and this is what Ortega proposed to his audience.

But the mission of universities does not end there, internally. It also has an external 'enlightening function' which, given its inoperability, has been taken over by the press and journalists:

Today's University should intervene as this type of University, dealing with the hot topics of the day from its own perspective: cultural, professional or scientific. In this way, it will not be a student-only institution, nor indeed a closed space ad usum Delphini, but, set in the midst of life, its priorities, its passions, must be imposed as a 'spiritual power' superior in standing to the Press, representing serenity as opposed to frenzy, serious sharpness as opposed to frivolity and frankness as opposed to stupidity (Ortega y Gasset, 2015 [1930]). 
The press and journalists-as Ortega knew only too well from his own experience-deal with the instantaneous, with shocking events, or the resonant and the noisy. Conversely, universities must focus on current culture, in other words dealing with the great and profound issues of the time enlightening amid chaos and disorder, leading the way on the fronts where society's progress hangs in the balance. This is the 'radical' university task, which is rooted in life and time.

In 1933, Fernando de los Ríos, Minister of Education of the Republic and friend of Ortega, announced the University Reform Act. The explanatory statement includes the Orteguian reformist argument and the distinction of the three functions. However, the coup d'etat by General Franco and the establishment of a national-Catholic regime aborted all expectations and hopes of reform and therefore ended with the institutionalisation of the cultural function of universities. With the return of democracy, the new University Reform Act LRU (Ley Orgánica de Reforma Universitaria, the LRU hereon) regained its university extension policy and denomination, with culture clearly listed as its third function-albeit with inconsistent and confusing language - and specific vice-rectorate management positions were created to manage the university extensions, cultural extensions, and cultural activities, and to meet the needs arising from an increasingly complex society.

\section{NORMATIVE STATUS OF THE CULTURAL FUNCTION}

Quite frequently, people working in the field of culture at their respective universities have the feeling their work is undervalued, in as much as the programmes and activities they run are considered somewhat complementary or 'ornamental' if the economic and financial environments turn bad. ${ }^{3}$ This vision is widespread, as reflected in a study on University Social Responsibility (USR) in Spain, coordinated by Margarita Barañano (2011), which obtained very low scores for both university extension and cultural initiatives. However, this reality could not be further from the spirit of legislators.

\footnotetext{
3 Anonymised concerns shared with the author in a meeting held in Cádiz, 2017.
}

The LRU (1983) and the Ley Orgánica de Modificación de la Ley Orgánica de Universidades (the Organic Amendment Law to the Organic University Regulation Law) (LOMLOU, 2002 and 2007) refer numerous times to culture either directly or indirectly (the 'system of living ideas' of an epoch) to highlight the objectives, functions, and missions of universities. These texts imply, without any doubt, that 'culture' constitutes the third function and/or mission of universities in Spain and is one of their main objectives.

Thus, the explanatory statement of the LRU begins by pointing out the need to reform universities. What is this need based on? Two new phenomena: firstly, the democratisation of university education, which has arisen both from a demand for vocational training and "from the growing and laudable interest in culture in its various forms" and "the foreseeable incorporation into the European area" with the consequent mobility of the skilled workforce (LRU, 1983).

Secondly, the democratisation of studies, is but

the last stage of a secular process of democratization of education and culture that has proved to be the strongest foundation underlying a stable, tolerant, free and responsible society. This is because science and culture are the best legacy adult generations can offer younger generations and the greatest wealth a nation can produce, without a doubt, the only wealth worth accumulating (LRU, 1983).

Therefore, the paragraph concludes that "scientific development, vocational training and the extension of culture are the three basic functions facing the 21st century, which must be fulfilled by that old and currently renewed social institution, the Spanish university" (LRU, 1983). Indeed, the LRU starts by mentioning the word culture four times in the second paragraph. ${ }^{4}$

\footnotetext{
4 The LOMLOU is expressed in the same way when it describes the functions of the Universidad Internacional Menéndez Pelayo (UIMP); the third supplementary provision 3 states that the UIMP will enjoy autonomy in the exercise of its teaching, research, and cultural functions, within the framework of its specific legal regime.
} 
In the explanatory statement of the LOMLOU, it says that "improving quality in all areas of university activity" is a fundamental goal of training the professionals required by society and, to do so, it is necessary to

develop research, conserve and transmit culture, enriched by the creative contribution of each generation and, finally, to constitute a critical and scientific instance, based on merit and rigour, which is a reference for Spanish society.

Furthermore, this law includes a novel aspect of lifelong training and points out that universities are obliged to make a 'cultural offer' available to anyone wishing to use it.

In both laws, article 1, paragraph 2, of the preliminary remarks specifies these reasons, explaining the "functions of the University at the service of society" (see the comparison in Table 1). Article 33, paragraph 1, of the LOMLOU (title IV) should be interpreted similarly. Speaking of teachings and titles, it argues that "teaching professions requiring scientific, technical or artistic knowledge and the transmission of culture are essential missions of the University".

One might complete this picture by evoking articles 92 and 93 of the LOMLOU. The first deals with international cooperation and solidarity, and points out that the University must promote activities and initiatives "that contribute to promoting the culture of peace, sustainable development, and respect for the environment, as essential elements of furthering social solidarity". The second cannot be more explicit and is entitled 'University Extension'. It states that:

it is the responsibility of the University to connect university students with the system of living ideas pertaining to their time. To this end, universities will arbitrate the means necessary to enhance their commitment to intellectual reflection, creation, and dissemination of culture. Specifically, universities will promote the rapprochement of humanistic and scientific cultures and strive to convey knowledge to society through the dissemination of science.

Table 1: Legislation regarding university culture regulation

\section{Bill of reform, Fernández de los Ríos, 1933 \\ (a) The vulgarisation or public dissemination of what constitutes a cultural body.}

LRU, 1983 (preliminary remark, article 1, paragraph 2) transmission and critique of science, technology, and culture.

(b) Preparation for the exercise of professional activities requiring the application of scientific knowledge and methods or of artistic creation.

(c) Scientific and technical support for cultural, social, and economic development, in both the national and autonomous regions (comunidades autónomas) of Spain.

(d) Extension of university culture.
LOMLOU, 2007 (preliminary remark, article 1, paragraph 2)

(a) Creation, development, transmission and critique of science, technology, and culture.

(b) Preparation for the exercise of professional activities requiring the application of scientific knowledge and methods or of artistic creation.

(c) Dissemination, assessment and transfer of knowledge to the service of culture, quality of life, and economic development.

(d) Dissemination of knowledge and culture through university extension and lifelong learning. 
The latter LOMLOU article can only create confusion, since it mentions ad intra activities for university students under the heading university extension, rather than ad extra activities for those who do not have access to university education. The purported recovery, in this article of law, of the Orteguian philosophy (i.e., 'living ideas in time') is carried out without the slightest understanding of the approach taken.

A quick look at these legislative texts makes it possible to draw three conclusions:

(a) Culture is the third mission or function of universities.

(b) University cultural policy has two different recipients: the university community and society.

(c) It is not exactly clear what the cultural function or mission consists of, because these normative texts move loosely among a semantic plurality without a coherent meaning or the implications derived from emphasising one or the other. There is a lack of legislative diligence in terms of consistency and language use.

A first examination enables us to draw, at least, the following meanings of the term culture..$^{\mathbf{5}}$ It designates:

(a) A sphere of society and life, together with science and technology or economics and politics, which can be preserved, created, developed, transmitted, and criticised, or any of the external 'environments' related to the University;

5 A meaning we could not find in the LRU or LOMLOU, but is used in reports on the social commitment of universities is that derived from a branch of sociology, referring to the 'culture of the institution' as a set of ideas and shared values that identify the characteristics of the organisation (the 'organisational culture'). See Influencing the institution's culture so that academic staff and students are motivated to engage with society (EU, 2001, p. 21). In this regard, Sennett says: "The culture of a company, like any culture, depends on the meaning that ordinary people associate with an institution rather than the explanation decreed by its higher levels" (2006, p. 65). (b) A result of all university activities_-knowledgeincluding lecturers and researchers, which must be 'spread', popularised, and disseminated to society;

(c) Specific activities, together with representative, charitable, and sports events that can gain 'academic recognition', promoting student participation. When talking about university colleges, it also refers to the obligation of universities to offer this type of activity to schools;

(d) A subtype of activities, such as those related to raising awareness of values such as peace and sustainability, solidarity, and equality;

(e) A specific type of offer for those who have lifelong learning needs or anyone who wishes to take advantage of this type of learning; ${ }^{6}$

(f) A way to address an understanding of the world, stating that "humanistic and scientific culture" must promote dialogue therein;

(g) A selection, based on criteria of excellence, of certain types of activities. Hence, when discussing the functions of the Menéndez Pelayo International University, it is argued that it must deal with 'higher culture'. Thus, semantic confusion is increased, although the importance of culture to the university remains unchanged-an inescapable function, and an essential mission—regardless of its form.

So, can we draw to a close our synopsis of the normative statute of culture in universities? Not at all, as this institution is also directly and specifically affected by the Ley de Patrimonio Histórico Español (the Spanish Historical Heritage Act, herin the LPHE) of 1985 as well as regional legislation on the matter. As the preliminary statement, in article 1 , paragraph 2 , states:

Spanish historical patrimony encompasses buildings and objects of artistic, historical, paleontological, archaeological, ethnographic, scientific, or technical interest. This heritage also

6 Explanatory statement, LOMLOU, 2007 
includes the documentary and bibliographic patrimony, the archaeological sites and areas, as well as nature spots, gardens, and parks that have an artistic, historical or anthropological value.

Universities own the aforementioned types of heritage; moreover, in many cases they are in themselves a cultural patrimony of society, given their origin and trajectory. Furthermore, Spanish universities possess the vast majority of scientific patrimony pertaining to Spanish society and thus constitute an important part of Spain's documentary and bibliographic heritage. In addition, the law recognises the capacity of universities as interlocutors and as consultative institutions, and the ability of their research centres to study and research all areas of heritage.

This approach defines the functional and cultural mission of universities and its normative statute demonstrates the specificity of university culture within a context where other instances (public administration or the market and the service sector) assume tasks of creation, diffusion, and programming. The policy and management of university culture does not (or should not) compete nor collide with the undertakings of public administrations. Indeed, as for education, health, or employment, it must provide cultural goods and services to society as a whole. Nor does it compete with private-sector programming or the promotion of cultural goods which generate direct economic benefit for the companies involved. However, universities can and should collaborate with such organisations, as well as with those in the service sector, provided they are framed within or subordinate to their own mission.

In this respect, 'university cultural' policy is anchored in teaching and research and has specific characteristics. Despite the implications of an ahistorical and elitist vision of culture, this is not a product per se, a commune bonum but a fact of human nature and social reality: human beings are constituted, as such, by symbolic systems. But many of these symbolic systems bestow meaning to human and social life, which is completely debatable from a university perspective. The mythical visions of the world, warlike or racist, anti-democratic ideologies, and so on, are cultural forms and expressions, but their dissemination and promotion cannot form a part of university cultural content. Universities are the seat of science and reason; therefore, the culture created, disseminated, and promoted by them must be:

(a) Critical, in that it submits ideas and practices to the scrutiny of reason and public debate, based on the search for the best reasoning or argument. The mythos gives way to logos.

(b) Scientific, in that it places the method by which truth is sought above any principle or faith. It undertakes to examine pre-judgement and only accepts the data from evidence and experimentation as a provisional truth.

(c) Creative, in that it is founded on the conviction that improvement is possible through appropriate innovation and the cultivation of imagination (Wright Mills, 1999).

(d) Academic, or integrating knowledge, both on a personal and social level. As Altamira states, those who have a university degree are also people. Also, Ortega claimed "the man of science ceases to be what sadly he often is today: a brute who knows a lot about just one thing" ${ }^{7}$ In the face of this bias it is necessary to promote the cives academicus.

(e) Current. Ortega's contribution also deserves to be restated today given its significance in that the University has to deal with the most relevant problems of its time and context such as climate change, intercultural coexistence or global inequality.

7 "Our best teachers live with a spirit fifteen or twenty years behind but are up-to-date in every detail of their science" (Ortega, 2015 [1930]). 
But, the cultural policy of universities, understood in all their complexity, does not finish there. It responds to a core mission of the institution which is not usually explicit in law, although it is in its statutes and this spirit is latently synthesised in all its activities: civic-political representation and moral leadership, in that universities embody the values cherished by society.

\section{THE PRAGMATIC STATUS OF CULTURAL FUNCTIONS}

After this synopsis, which strongly emphasises the legal status of cultural functions, we will now explore what actually happens in terms of culture at universities, or to be more precise, what has actually been done in recent decades. We consider three aspects: discourses, organisational forms, and the fields of activity encompassed under the umbrella of culture.

\section{Discourses}

Although the current legislation clearly states that the third function or mission of universities is culture, the last 20 years have witnessed other discourses of a purposeful nature. The latter have supplanted this third purpose and have moved to several areas of university activities under pressure to produce regional economic development in a globalised world when faced with cuts in public funding. In this context, two new areas of competition, as well as the redefinition of the university model, have emerged from the same origin: knowledge transfer and technological innovation ("third-stream mission of economic growth", Lester, 2007a) and corporate social responsibility (CRS) or 'social commitment' (E3M, 2012). ${ }^{8}$ All the authors who take this approach share an opinion on one of the great myths concerning universities: they must leave their ivory towers. The other myth is the claim that universities have become commodified.

8 Beraza and Rodríguez (2007) very clearly describe the evolution of universities towards this third entrepreneurial mission.

\section{Transfer and innovation}

The function of performing research was introduced by Humboldt in German universities when a new model (or second-generation) of universities emerged. This function became increasingly important after the industrial and bourgeois revolutions, and further grew from the 1980s with intensified globalisation and a boom in the knowledge economy.

Until the digital revolution changed their historical physiognomy, in the context of intense and extensive transnational flows, universities became established in this territory and had two fundamental sources of development: a highly qualified population and new ideas (Lester, 2007a). They became, therefore, fundamental players in local economic development.

Universities and their internal research groups have been motivated by project funding agencies (European, state, and autonomous regions) to create and launch institutes and science-technology parks. These have become hubs of knowledge transfer (in the form of patents) and innovation, research groups, traditional companies, and start-ups. Thus, research and technological development (known as RTD in the European Union) has now become the magic formula that expresses the development of the research function. It could be said that we are faced with a logical corollary, were it not for the fact that this process has been interpreted as the birth of the third mission and thus also of new generation of universities: 'university companies', based on the entrepreneurial spirit (Etzkowitz and Leydesdorff, 2000; Jongbloed and Goedegebuure, 2003; Wissema, 2009). This process has generated tensions and confrontations within universities, because it necessarily raises issues such as the possible loss of autonomy and academic freedom, although, as Lester asserts, the underlying trend towards a greater commitment to economic development is very clear (2007, p. 12). But does this imply that all universities should inevitably be reconsidered in company-like hues and that this third function-economic knowledge transfer-has to be implemented in all of them? Lester's vision, founded on research into innovation systems in 23 different 
environments, is much more subtle: success stories in this field are well known but are in the minority and are atypical (e.g., Stanford, Cambridge, or MIT). Furthermore, the creation of companies or filing of patents in the university environment is very limited (of the 150,000 companies registered in the US in 2001, only 3,700 were by universities and many had little or no economic return). Also, the possibility of universities making a profit from this mercantile dimension is very low. Finally, patenting and registering licenses is only one way to transfer knowledge. In conclusion, we need a broader perspective of the role universities play in local economies. Those Universities are creators, recipients, and interpreters of innovation and ideas, sources of human capital and key components of infrastructure and social capital (2007, p. 14).

The imperative that universities should be committed to their environment has too often been restricted or inappropriate for the prevailing economic environment. The word technology is understood outside its social dimension (for instance, the welfare state and the internet are social technologies) but the term innovation applies exclusively to technological innovations (OECD, 2005).

In addition to a reductionist view of transfer, this approach also adopts a mistaken view of innovation. As shown by the evidence gathered by the Local Innovation System Project at the MIT, directed by Richard K. Lester (2005): "universities can play a central role by providing a public space to promote dialogue on the dilemmas of the future of society". This can take the form of meetings, conferences, forums, etc., where ideas may arise and provide novel ways of dealing with social problems; however, the report also states: "all too often, the importance of this university role as a public space and its contribution to local innovation has been underestimated". This conclusion is fully aligned with the cultural function and in this respect universities can represent a public space relevant for socio-cultural innovation.

But what is innovation? As with culture, just invoking that word generates positive resonance: it is something desirable and beneficial per se. In which case, should subprime mortgages, atomic weapons, tax havens, artificial intelligence, or new methods of global terrorism not also be considered innovations? Central problems are still normative (differentiating between what is good, correct, acceptable, etc., and what is not), prospective (what is possible or impossible), are organisational (how to generate operational structures and cognitive and relational resources to cope with them), or in last resort, political, social, or cultural problems. Deciding which innovation to green-light and which should be subject to discussion by universities is multidimensional, and should entail the systematic application of human creativity and knowledge to search for solutions to social problems (Lester, 2017).

\section{University social responsibility}

A second discourse which refers to universities' social commitment to their environment has more recently come to light. This can be likened to corporate social responsibility (CSR) but has been redefined as university social responsibility (USR; Ariño and González, 2011; E3M, 2012) ${ }^{9}$. The surprising success of this discourse in Spain could well be related to a compensatory reaction to the emphasis on business transfer as a third mission. It has gained so much importance that there are already universities that presume to be pioneers in the introduction of specific vice-rectorate management positions charged with this role. Furthering this aim, there have been reports, publications, PhD theses, and meetings called by central government, the Conferencia de Rectores de Universidades Españolas (CRUE, the Spanish Universities Rectors Conference), or Social Committees ${ }^{\mathbf{1 0}}$. Some universities have published specific reports while others have included

\footnotetext{
9 The reader can consult a large number of publications on this topic at http://compartiendoexperienciauniversitaria.blogspot. com.es/p/articulos-sobre-rsu.html. Also see E3M, 2012, where it is explicitly recognised that there is no clear 'third mission', even though this is the title of the report (E3M, 2012, p. 6).

10 The following conferences on university social responsibility have been held in this respect: I Jornada Iberoamericana sobre la Responsabilidad Social de la Universidad (23 October 2008, Úbeda), organised by the UNED and MAPFRE; /I Jornadas de Responsabilidad Social de la Universidad (Universitat Jaume I, 24-25 May, 2010); and III Jornadas que se celebraron en la Universidad de Zaragoza on 24 and 25 May 2011. Regarding theses see Gaete, 2012.
} 
USR in their statutes ${ }^{\mathbf{1 1}}$ and have delegated this task to their vice-rectorates. The 2015 the university strategic plan argued that it was "essential to strengthen this function" and at some point, apparently without applying much consideration, it was called the third mission (Estrategia Universidad 2015, p. 27). ${ }^{\mathbf{1 2}}$ The Social Committee Forum of the Universidades Públicas de Andalucía organised an international conference where it announced the creation of the first overview of USR. ${ }^{13}$ We can conclude that the last decade has witnessed a proliferation of USR-related actions, especially in Latin America. Despite this, it is far from clear what is effectively understood by such or what its normative anchorage is.

\section{An open-ended and confusing definition}

Browsing the texts of the LRU (1983) and the LOMLOU (2007) reveals that the concept of USR does not exist in the regulatory framework of the functions and missions of universities in Spain. This has not prevented it from being enthusiastically embraced by certain areas of knowledge and university governance teams, nor its inclusion in the 2015 University strategic plan. What is it, then, and to what does it owe its success?
On the one hand, in a study by the Fundación Carolina, De la Cuesta et al. identify it with

offering educational services and knowledge transfer, following principles of ethics, good governance, respect for the environment and social commitment, as well as the promotion of humanistic values, thus taking responsibility for the consequences and impacts derived from ones actions. It involves accounting to society for the positive advances and negative results regarding the commitments made with stakeholders and, in general, human rights, the environment, good governance and social commitment (De la Cuesta, et al., 2010, p. 236).

This is also the definition followed by López and Larrán at the above-mentioned international meeting (López and Larrán, 2010). On the other hand, another paper from the same forum, written from the perspective of the various social committees, states that USR

considers the possibility of connecting knowledge management to local, national and global needs, promoting the social utility of knowledge in such a way as to contribute to improving the quality of life of the people and institutions concerned or University stakeholders (Gentil, 2012). ${ }^{\mathbf{1 4}}$

11 According to the Universidad Nacional de Educación a Distancia (UNED-the Spanish Open University): "The UNED's mission specifically aims for the university to contribute to a model of innovation according to socially responsible and sustainable social, cultural, economic, and environmental development. Social responsibility should be understood as a reconceptualisation of the whole institution, in the light of the values, its objectives, forms of management, and initiatives imply a greater commitment to society and a contribution to a new model of more balanced and sustainable development" (UNED, 2016).

12 It refers to the academic and social values to defend the democratic values of progress, freedom, and justice.

13 Basically, this overview panel consists of Spanish and Latin American universities: "Professionals agree on the need to incorporate social responsibility as a way of evaluating, regulating and improving the quality of education and Institutions themselves. It is key for universities to be socially responsible if they are to promote that same feeling and obligation in citizens" See http://noticias.universia.es/vida-universitaria/ noticia/2014/02/28/1085005/crean-primer-observatorioresponsabilidad-social-universitaria.html. mixed here: (a) provision of a service based on principles or standards; (b) accountability of the results; (c) social utility of knowledge. On many other occasions, USR is associated in a very specific way with the university's contribution to sustainable development.

As Barañano emphasises in the most extensive study carried out so far on the presence of USR in Spanish universities, there is in fact no clear consensus on its definition. Does it transversally affect all university functions, or is it a new function? Is it a specific area of activity (social action, cooperation, volunteerism, etc.) or

14 A-let us say-hearsay definition proposed in a text talking about the functions of universities, and which omits any reference to the legislation in force.
It should be noted that three different concepts are 
a new mission (to meet the demands of the productive system)? Is it a perspective (social commitment) from which all the functions of universities are interpreted or an instrument to measure socio-economic impact and to provide accountability to society? Or is it new way of talking about quality and/or values or a means to gain a public reputation (15 $^{\mathbf{1 5}}$

Also, all these texts agree that it is a transfer to public and private university organisations of a policy that has been implemented in business schools and large companies since 1953 and, even more so, since the 1980s.

The imposition of business university social responsibility The introductory text of the website ${ }^{\mathbf{1 6}}$ in the afore-cited international meeting held in February 2012 in Cádiz began by pointing out that

the new way of understanding and exercising business management of Corporate Social Responsibility is of interest to different agencies and institutions at both the national, regional and international levels [...] In this way, a regulatory framework has been created, to which the business organizations have been voluntarily subscribing [...] The development of practices of University Social Responsibility implies the reformulation of the traditional methods of university management, where the satisfaction of the different social agents has become one of the main keys for long-term success of the University.

In the classic Postcapitalist Society by Peter F. Drucker (1993), the author recalls the importance that large US business schools placed on so-called business

15 What happens in other countries? Indeed, it has had a wide diffusion and impact in the Ibero-American world and, furthermore, one can find a large number of articles published over the last five years on the internet, which study USR in the main elite universities in England, Germany, India, Nigeria, Ukraine, or in Muslim universities, which insist on the need to incorporate USR into university policies. Nejati et ál., 2011; Mehtqa, 2011; Brown and Clock, 2009

16 Note, at the time of editing this article and verifying the electronic addresses, the website no longer existed. ethics in the late 1980s and early 1990s; they were devoted to censoring shady and illegal procedures to obtain profits and promote responsible behaviour towards society: "Ethics could also be productive and beneficial", it was said, decontextualising this principle from its relationship with trends in consumption patterns. More recently, an ISO 26000 standard has been approved for social responsibility; it requires the exploration of seven dimensions: organisational governance, human rights, employment practices, environment, justice practices, consumer issues and involvement, and community development.

Both Drucker in 1993 and Nejati et al. in 2011 argue that social responsibility is related to the relationship between an organisation and its environment, but neither of them point out that a company's prime goal is to obtain profits. ${ }^{\mathbf{1 7}}$

Thus, the nature of a business organisation determines the existence of an autonomous economic logic which Milton Friedman formulated with his habitual frankness and audacity: "A company only has one responsibility, i.e., its economic results". Bernard Mandeville had written centuries before: “Bare Virtue can't make Nations live In Splendor; they, that would revive A Golden Age, must be as free, For Acorns, as for Honesty".

In our consumer society with instantaneous communication and ubiquitous, democratic, and globalised information, it now seems that the conditions for doing business and for making profits have changed without transforming the ultimate goal. These are the conditions of mature, informed, demanding consumers, which lead companies to find ways of making ethics and social responsibility profitable. But, then, we should ask whether this is simply a new rhetoric for a new capitalism? Why has the reputational issue gained so much

17 Nejati et al. state that "CSR requires companies to undertake to balance and improve environmental and social impacts without damaging economic activity" (2011, p. 441). 
importance, a new term to replace the classic image? If all this corporate social responsibility discourse had actually amounted to more than it preached, how can one explain that during its peak period of growth and splendour we have witnessed the greatest concentration of wealth over the last hundred years? This seems to have triggered a worldwide crisis with the intoxication of the system through fraudulent products, the flexibilisation of working conditions, policies of austerity and wage cuts, an increase in ecological threats. Drucker (1993) and Nejati et al. (2011) hold, almost 20 years apart, that it is not a mere reputational issue, but in this era-postcapitalist according to Drucker-“Economic performance is not the sole responsibility of a company" and that "an organisation has full responsibility for its impact on the community and society". Of course, we can agree on this as an act of faith, but it is, in any case, a political responsibility not derived from its economic constitution. In other words, it is not in its nature as a business organisation and therefore will only be voluntarily embraced, by the conviction of its leaders, for strategic or tactical reasons, or by the force of legal imposition.

One of the strategic reasons why CSR is incorporated into the era of consumer capitalism is, no doubt, as we have already indicated, because product differentiation requires 'added value'. This value can come from symbolic elements such as brands that produce identity, prestige, or distinction, but also relate to moral elements in a society concerned about environmental or social issues. But are universities companyies?

\section{Universities public services}

University organisations have a mission "to carry out the public service of higher education" (art. 1, LOMLOU). Their primary goal-which they do not bestow upon themselves and is, therefore, unaffected by autonomy-is not the accumulation of capital and sharing the profits. Their nature and their essence is to provide a public service. This is the intrinsic social value that affects all university activity.
There is some controversy about how to understand the concept of public service in the era of the so-called welfare mix or 'welfare production/provision mixture', but in the light of community law, public service is "that material activity of exclusive public ownership aimed at satisfying essential collective needs" (Moles, 2006). This notion entails ideas of utility, profit, or benefit in favour of society. The satisfaction of needs that exceed purely individual interests is pursued and respect for the principle of equality is required.

Community law has developed the concept of 'economic service of general interest' as a common denominator of the different European legal traditions and which includes the provision of universal service as its main obligation. In other words, it is obliged to provide service in every case, at a certain level of quality, which is oriented to the general interest and at an affordable price, regardless of the economic, social, or geographical situation of the citizen (Moles, 2006, p. 220).

Therefore, what is the social responsibility of universities? In my opinion, it is to fully develop its nature and fulfil its legal mission. However, this does not take place outside the historical circumstances and conditions of knowledge production. For example, scientific knowledge is now produced in large infrastructures and using resources which impact the environment, and in a context where this impact is better known today than it was years ago; at the same time we must be mindful of the grave problems affecting our planet and society and help to find solutions based on our specific understanding. Ortega was referring to this when he said that "universities must also be open to the present day; moreover, it must be in the midst of it, immersed in it".

In summary, social responsibility is not an added and complementary value, but rather, an intrinsic, constitutive, and transversal one. Universities cannot overlook the social impact of their actions without contradicting their own nature, which does not happen in private businesses. But are universities capitalist companyies? 


\section{Organisation of the cultural function}

An important aspect to consider here is the form of structuring this cultural dimension. The teaching mission is implemented in the official centres (schools, postgraduate centres, and institutes) and is organised through a central service that has a coordination function (student, undergraduate, postgraduate services, etc.), dependent on one or two vice-recorate officials (according to the moment in history).

The research mission is carried out by each investigator, is implemented in the departments and research institutes, and the process is coordinated by a central service, dependent on a vice-rectorate. In both cases, state legislation, autonomous regional regulations (on the creation of educational centres and institutes), and the statutory regulations of each university, regulate the organisation and implementation of the corresponding activities.

The cultural mission is fulfilled a very different way: in no man's land. There is no state or regional legal regulation. Article 93 of the LOMLOU is limited to stating that universities will arbitrate the "necessary means' and universities mainly refer to university extension services, but in no case are these exhaustive, nor do they control many other cultural activities that are more or less connected with the core cultural area (publications services, sports ${ }^{\mathbf{1 8}}$, etc.).

To this we must add that some of the services provided by universities are inherently multi-dimensional and serve all three functions at the same time, and these are not easy to tell apart. Paradigmatic cases are library and documentation services or resource centres for learning and research, publications services, and student care services, some are ambivalent and have a mandate to fulfil the main, secondary, or complementary function, while others undertake cultural activities.

18 It is too easily forgotten that the word culture comes from cultivation and, with respect to sports both physical culture and culturism are derived therefrom.
Therefore, each university has regulated the implementation and organisation of this mission in a different way, although all or most of them share certain common traits:

(1) The implementation of the cultural function is disperse; it can be developed, without an imperative mandate, by teaching centres, departments, institutes, higher education colleges, and individual centres.

(2) In all or most of them there is a superior body (for example, a vice-recorate official) that binds together the different dimensions of the cultural mission, especially the representative omnibus dimension. In fact, the so-called cultural outreach services, when they exist, only coordinate and manage a small part of the cultural activity undertaken by each university.

(3) Even so, there is usually no single instance of coordination, supervision, or global management. Rather, different services or structures operate with a high degree of autonomy, which assume some of the sub-dimensions of the cultural function (such as physical and sporting activity, outreach activities, publications services, university summer schools, universities for older adults, sustainability, etc.), without it being clear whether these activities and services are related to the cultural dimension in all cases. They have acquired such organisational autonomy that their link to different vice-rectorate officials depends on discretionary factors rather than the functional coherence of the cultural mission. Some structures undertaking this function may even operate like 'sunless planets', whose autonomy is hard to justify from the viewpoint of public transparency, organisational effectiveness, or social commitment.

(4) Universities have not started dialogue on how to modify this third mission in accordance with the impact of communication and information technologies, especially the cooperative applications emerging with the so-called Web 2.0. 
Compared to other areas of university organisation, this situation reveals both the pragmatic weakness of the cultural function in each university and the lack of a clear vision by governing bodies and the university community in general. We might reach the same conclusion when we speak of the organisational status at the national level: there is no specific sector in the CRUE that coordinates these activities and cooperates to resolve the needs derived from this function. Moreover, this did not happen due to a lack of bottom-up endeavour, indeed the CRUE has shown great sensitivity towards this need and stated its importance since 1991. However, it has not yet received the answer it deserves. ${ }^{19}$

On the one hand, there are, of course, thematic structures such as synergies, for the coordination of university orchestras, the international university readers' network, science outreach groups, sustainability or library networks, healthy universities, university publishers, lifelong training or universities for older adults, and theatre. However, these are initiatives that have acquired or may acquire an unnecessary functional autonomy and which offer an image of fragmentation or splintering from the cultural dimension. On the other hand, there have been several attempts at substate or trans-state territorial articulation: The G9, the watchtower network of Andalusian Universities, the Xarxa Vives of the Catalan-speaking universities, or the Gaelic-Portuguese network $(3+3)$.

19 In particular, the following endeavours should be outlined: In February 1991, the vice-rectors of most public universities met at the Universidad de La Laguna. Attendees at this meeting recognised the need to establish professional technical teams to provide stable management resources to CRUE members. A university extension coordination group was set up and initiated contacts with the CRUE to become a sector within it, as well as with the Ministry of Culture and some regional councils in order to establish joint institutional collaboration channels. In 1992 and 1993 the university extension vice-rectorate plenary body met on several occasions (Córdoba, Alicante, and the Baleares) culminating in the university management conferences in Barcelona, held in November 1993. In 1998, two other events took place: in Valencia addressing a reflection on the reality of university culture at the threshold of the 21 st century. This meeting served as a prelude to an international Ibero-American conference in Oviedo commemorating a hundred years of university extension. In both cases, the need to constitute a dedicated sector was raised once again. In 2002, the 'Declaration of Alicante on University Extension' was written and presented to the CRUE at the Rafael Altamira International Conference in Alicante.

\section{Expansion of the cultural agenda}

We use the expression cultural agenda here in its broadest sense, to designate the subjects or tasks related to culture at universities, which form part of a more or less explicit plan, in the form of a schedule or a calendar of activities. In no way do we confine it to the powers of a vice-rectorate or a specific organisational structure, because, as we have said, Spanish universities are far from such systematisation. We start from the evidence obtained by analysing the websites of several universities and of experiences, based on various regional or general meetings, in particular, the one held in July 2017 at the University of Cádiz under the title University and Culture: Balancing a Relationship. ${ }^{\mathbf{2 0}}$ The term agenda comes from the Latin agere and designates 'what is to be done' because it is planned. What are the Spanish universities committing to in this field of culture? Table 2 offers an approximate scenario, without claiming to be exhaustive or systematic, based on the reflections we have presented in this article.

The items could be classified according to: their orientation, inward (university community-integral formation) or outward (extension, dissemination, or contribution to society and leadership); whether the activities belong to the field of humanities, social sciences or basic sciences; whether they consist of events, goods, or services; according to their periodicity or sequence of repetition (lectures, seminars, conferences, or congresses); according to their funding base (own, mixed, or subsidised); depending on the type of actions involving participation (creation and active production or receptive assistance), and so on. Our goal here is to show its recent expansion more than the internal systematics, be they derived or expressed.

To round off this presentation, an analysis of the contents of each area and their preferred recipients could also be carried out. However, for the moment, here we simply present a list of areas, and below we highlight some specific areas which deserve special attention.

20 See: https://celama.uca.es/68cv/seminarios/b14 
(1) First of all, it may be appropriate to highlight that research and teaching in cultural sectors, participation, and cultural management have grown extraordinarily in these years. Working groups, journals, and Masters' degrees have been created, first as the university's own qualifications and then as official qualifications. In particular, in 1989 the Universitat de Barcelona Master degree was created; in 1990, the association of cultural managers was established; followed by the Universitat de València Master degree in 1993. In this period, we also saw the advisory function of strategic planning for town halls or large cultural organisations.

(2) The importance of university heritage that, as mentioned, has a simultaneous general and specific character (encompassing all kinds of items), because a fundamental part of it is the result of teaching and research activity specialised in science. Historical universities not only have a wealth of assets and real estate, as well as bibliographic and documentary assets, but they have also accrued collections of natural history, medicine, or engineering to cater to teaching and research needs which have been transformed into very singular science museums. Many of these universities may possess 20 or 30 different collections with hundreds of thousands of exhibits.

(3) The new recipients of cultural extension. Two types of recipients should be specifically highlighted: older adults (lifelong learning) and foreign students, especially participants in the Erasmus programme. Schools or universities for the former have been created and since 2004, most of them have been integrated into a state association with 45 programmes and more than 50,000 students. ${ }^{21}$ Regarding foreigners, the international theatre programme Erasmus scene network is noteworthy. ${ }^{22}$

21 See the state association of university programmes for older adults: http://www.aepumayores.org/sites/default/ files/diptico_aepum_castellano.pdf

22 This project is run by the Universitat de València: http:// www.escenaerasmus.eu/
(4) Summer courses, schools, or universities. In the last 40 years all universities have experienced extraordinary growth in this type of multi-topic programme, which combines seminars with entertainment activities. Their success has partially been linked to their inclusion in the free-elective credit student curriculum. They must now reinvent themselves in a new sociocultural (digital revolution) and university (curriculum modification) context.

(5) Innovation and social inclusion programmes. Beyond the mere cultural extension or dissemination of science, some universities are running intervention programmes for social inclusion. There, they do not merely debate social problems, but they generate 'laboratories' where they can discover, from the interrelation of different knowledge areas, the opportunities arising to deal with new vulnerabilities: inmates or ex-offenders, school drop-outs, female victims of violent abuse with protection orders, immigrant populations, etc. ${ }^{23}$ These 'social outcasts' are not uncultured people, but merely belong to other cultures.

In short, since the democratic transition and the university reform there has been strong growth and expansion, in several ways and for various reasons, of the university cultural agenda and offer. However, the most radical change-the incorporation of information, communication and organisation technologies or general purpose technologies-has not yet been tapped to its full potential to create think-tanks, sociocultural innovation laboratories, or mediation spaces in collaboration with society and its organisations. This will mean a change in universities' operating scales (extension is not circumscribed to its territory of implantation) but also a transformation in how to organise that operation (networks generating: regional, state, or intercontinental synergies, such as with educational television programmes).

23 See Mil formas de mirar y de hacer (UPO; A thousand ways to see and do) https://www.upo.es/portal/impe/web/contenido/7dd9ab71 08d6-11e7-8aa8-3fe5a96f4a88?channel=d3563863-2f47-11deb088-3fe5a96f4a88 
Table 2: Pragmatic field of university culture

FIELD

Arts: music, theatre, dance, artistic creation in general, and concerts

Training groups or classes: reading, writing, cinema forum, and video games

Exhibitions: based on their own sources, academic research, or external offers

Debates, conferences, forums, seminars, and schools

Science outreach in the form of lectures, conferences, congresses, seminars, and publications

Heritage, collections, and museums

Botanical gardens

Publications service

Library service: bibliographical heritage, documentary heritage, etc.

Summer courses, schools, and universities ${ }^{\mathbf{2 4}}$

Universities for older adults ${ }^{25}$

Colegios mayores (student housing)

Foreign students and Erasmus

Alumni

Research

Masters

Audiovisual and digital workshops

Physical and sporting activity

Chair in cultural affairs

Outreach journals and magazines

Territorial projection

Social inclusion programmes

Associations

Socio-cultural innovation programs

Values: sustainability, peace, equality, inclusiveness, and democracy

Innovation Lab

SOURCE: Elaborated by the author

24 The Universidad del País Vasco is in its 36th edition; the Universitat de València is in the 31st; UNED is in its 28th, and the Universidad Complutense de Madrid is in its 29th.

25 At the beginning of the 1980s, programmes were run at universities such as those in Girona and Lleida in the framework of university extension; in 2004, the state association was created: http://www.aepumayores.org 


\section{PUBLIC ACADEMY DEMANDS}

As we have seen throughout this text, university culture is more than a specific agenda or cultural offer and is not solely concerned with the so-called cultural sector of society. Culture is objective while its mission and function are essential and transversal; it is ingrained in its other functions and is inseparable from these.

Likewise, we have found that this function is dispersed. This means that it commits everyone, everywhere, and all the time. However, 21st century universities are highly complex; they offer a diverse range of undergraduate, master's, and doctorate degree programmes, in many areas of knowledge, and research groups. In this scenario, within the interstices of departments, faculties, and institutes, we can lose sight of the most relevant issues: (a) comprehensive training and (b) the ability to identify the challenges to be resolved based on reason and empirical evidence, as well as understanding their scope and significance.
Let us remember that Ortega said "it is hard to live up to the times and especially to the ideas of our time". These imperatives are now even more valid if we are to achieve the advancement of knowledge and the improvement of society. Universities must be able to address the most peremptory, complex, intricate, and relevant issues, and treat them with rigour, audacity, and intrepidity alongside citizens to come up with answers within the framework of an open conversation, where the best arguments make headway. Recalling the sabatinas, or 'Saturday schools', the 21st-century public academy-using the contemporary means at its disposal—should be a space are sharedin which the problems and challenges concerning us today. The issues upon which our quality of life depends, for both those living today and future generations, should be addressed and answered by the universities through sociocultural innovation. In this way, they would simply be doing what is in their nature as public services. This is our service and commitment and our greatest social responsibility, and it should not succumb to fashionable rhetoric or other alien narratives.

\section{REFERENCES}

Altamira, R. (1949). Tierras y hombres de Asturias. México: Revista Norte.

Altamira, R. (2012). Cuestiones obreras. València: Publicacions de la Universitat de València.

Ariño, A., and González, A. J. (2011). La dimensión cultural. In M. Barañano, La dimensión social como misión en las universidades españolas y su contribución al desarrollo sostenible. Diagnóstico y buenas prácticas (p. 75-92). Madrid: Ministerio de Educación.

Ariño, A., and Romero, J. (2016). La secesión de los ricos. Barcelona: Galaxia Gutemberg.

Barañano, M. (2011). Responsabilidad social de la Universidad y desarrollo sostenible. Madrid: Ministerio de Educación.

Beraza, J. M. ${ }^{a}$, and Rodríguez, A. (2007). Evolución de la misión de la Universidad. Revista de Dirección y Administración de Empresas, 14, 25-56.

Brown, E., and Clok, J. (2009). Corporate Social Responsibility in Higher Education. ACME: An International Journal for Critical Geographies, 8(3), 474-483.

De la Cruz, C., and Sasia, P. (2008), La responsabilidad de la universidad en el proyecto de construcción de una sociedad. Revista Educación Superior y Sociedad, 13(2), 17-52.

De la Cuesta, M., De la Cruz, C., and Rodríguez, J. M. (coord.) (2010). Responsabilidad Social Universitaria. La Coruña: Netbiblo.

De la Cuesta, M., and Sánchez, D. (2012). Responsabilidad social universitaria 2.0. La Coruña: Netbiblo.

Del Huerto, M. E., Almuiñas, J. L., and Caramés, J. L. (2001). La Extensión Universitaria: un reto a la gestión cultural de las universidades del siglo XXI. Oviedo: Trabe.

Drucker, P. F. (1993). Post-capitalist society. New York: HarperBusiness.

E3m. (2012). Libro Verde: El fomento y la medición de la «Tercera Misión» en las Instituciones de Educación Superior, proyecto europeo: «E3m: European Indicators and Ranking Methodology for University Third Mission» (European Comission). Accessed on the 13th of September 2017 at http://www.e3mproject.eu/ 
Etzkowitz, H., and Leydesdorff, L. (2000). The Dynamics of Innovation: From National Systems and 'Mode 2' to a Triple Helix of University-Industry-Government Relations. Research Policy, 29, 109-123.

Etzkowitz, H., Webster, A., Genhardt, C., and Terra, B. (2000). The Future Of the University and the University of the Future: evolution of ivory tower to entrepreneurial paradigm, Research Policy, 29, 313-330.

Ferrero, R. (1987). Capítulos de 1517. Acerca de una reforma de la Universidad de Valencia. In Universidades españolas y Americanas (p. 141-149). València: CSIC.

Gallego, J. (1980). La facultad de Artes de la Universidad de Valencia desde 1500 hasta 1525. Escritos del Vedat, 10, $215-285$

Gaete, R. (2012). Responsabilidad Social Universitaria: Una nueva mirada a la relación de la Universidad con la sociedad desde la perspectiva de las partes interesadas. PhD Thesis. Valladolid: Universidad de Valladolid. Accessed on the 13th of September 2017 at https://uvadoc.uva.es/bitstream/10324/923/1/TESIS148-120417.pdf

Gaete, R. (2015). El concepto de responsabilidad social universitaria desde la perspectiva de la alta dirección. Cuadernos de Administración, 53(31), 97-107.

Gentil, C. (2012). Responsabilidad social corporativa ¿un mito en tiempos de crisis?, 30 Jornadas de Gerencia Universitaria. Universidad de Cádiz. 24-28 de octubre de 2012. Accessed on the 13th of September 2017 at http://jornadasdegerencia.uca.es/docs/ponencias/xxx-gerencia-cadiz-018.pdf

González, O. J., et al. (2015). La responsabilidad social en las universidades españolas 2014/2015. Alcalá de Henares: Instituto Universitario de Análisis Económico y Social.

Hill, R. P. (2004). The socially responsible university: Talking the talk while walking the walk in the college of business. Journal of Academic Ethics, 2(1): 89-100.

Jongbloed, B., and L. Goedegebuure (2003). De la universidad emprendedora a la universidad stakeholder. In Universidades y desarrollo territorial en la sociedad del conocimiento (vol. 1) (p. 153-177). Barcelona: Diputación de Barcelona / Universitat Politècnica de Catalunya.

Larrán, M., and López, A. (2010). Una propuesta de memoria de responsabilidad universitaria como vía de diálogo con los diferentes grupos de interés. In M. de la Cuesta, C. de la Cruz, and J. M. Rodríguez (coord.) Responsabilidad Social Universitaria (p. 99-124). La Coruña: Netbiblo.

Lester, R. K. (2005). Universities, Innovation, and the competitiveness of Local Economies. Cambridge, MA: MIT.

Lester, R. K. (2007a). Universities, innovation, and the Competitiveness of Local Economies. A Summary Report from the Local Innovation Systems Project - Phase I. Cambridge, MA: MIT.

Lester, R. K. (2007b). Innovation, Universities and the Competitiveness of Regions. An Overview. Technology Review, 214, 9-30.

Lester, R. K. (2017). A global Strategy for MIT. Cambridge, MA: MIT Press.

López, A., and Larrán, M. (2010). Pasado, presente y futuro de la responsabilidad social universitaria: propuesta de un observatorio, I Jornadas Internacionales sobre Responsabilidad Social Universitaria, 20 febrero, 2014.

MEC (1991). Proyecto de Ley de Reforma Universitaria presentado a las Cortes por el Ministro de Instrucción Pública Fernando de los Ríos el 17 de marzo de 1933. In Historia de la Educación en España. IV. La Educación durante la Segunda República y la Guerra Civil (1931-1939) (p. 202). Madrid: MEC.

Mehtqa, S. R. (2011). Corporate Social Responsibility and Universities: Towards an Integrative Approach, International Journal of Social Science and Humanity, 4(1), 300-304.

Moles, R. J. (2006). ¿Universidad S.A.? Público y privado en la educación superior. Barcelona: Ariel.

Morales, I. (2010). Dossier de Trabajo: Competencias Culturales de los Universitarios. Accessed on the 14th of September 2017 at http://www.observatorioatalaya.es/es/48

Muñoz, J. (2007). Introducción. In J. Muñoz (ed.), Misión de la Universidad (p. 13-56). Madrid: Biblioteca Nueva.

Muñoz, C., (2012). Responsabilidad Social Universitaria. Aportes al enriquecimiento del concepto desde la dimensión de las prácticas. Accessed on the 14th of September 2017 at https://www.ucm.es/data/cont/docs/599-2013-11-16Doc_23.pdf

Nejati, M., Shafaei, A., Salamzadeh, Y., and Daraei, M., (2011). Corporate social responsibility and universities: A study of top 10 world universities' websites, African Journal of Business Management, 5(2), 440-447.

OECD, (2005). Manual de Oslo. Guía para la recogida e interpretación de datos sobre innovación. Paris: OECD-Eurostat. Ortega y Gasset, J. (2015 [1930]). Misión de la Universidad. Madrid: Cátedra. 
Readings, B. (1996). The University in Ruins. Cambridge: Harvard University Press.

Reed, D. (2004). Universities and the promotion of corporate responsibility: reinterpreting the liberal arts tradition. Journal of Academic Ethics, 2, 3-41.

Rubiralta, M., and Barañano, M. (2010). Responsabilidad social universitaria. In M. de la Cuesta, C. de la Cruz, and J. M. Rodríguez (coord.), Responsabilidad Social Universitaria (p. 127-139). La Coruña: Netbiblo.

Sennett, R. (2006). La nueva cultura del capitalismo. Barcelona: Anagrama.

Sevilla, C. (2010). La fábrica del conocimiento. La universidad-empresa en la producción flexible. Barcelona: El Viejo Topo.

Solé, F. (2003). Universidades y desarrollo regional. In J. Vilalta, and E. Pallejà (ed.), Universidades y desarrollo territorial en la sociedad del conocimiento (vol.1) (201-223). Barcelona: Diputación de Barcelona / Universitat Politècnica de Catalunya.

UE. (1995). Libro Verde de la Innovación. European Commission.

UE. (2001). Libro Verde. Fomentar un marco europeo para la Responsabilidad Social en las Empresas. European Commission.

UNED. (2016). Responsabilidad social de la UNED. Accessed on the 14th of September 2017 at http://portal.uned. es/portal/page?_pageid=93,25080930\&_dad=portal\&_schema=PORTAL

Vallaeys, F. (2008). Responsabilidad Social Universitaria: una nueva filosofía de gestión ética e inteligente para las universidades. Revista Educación Superior y Sociedad, 13(2), 191-220.

Varios (2007). La extensión universitaria en Gijón. En el primer año de 1902 a 1903 (facsimile edition). Oviedo: Universidad de Oviedo.

Vicente, F., and González, A. (2002). Concepto y misión de la Universidad. De Ortega y Gasset a la reforma universitaria del nacional-catolicismo. Revista Española de Educación Comparada, 8, 137-173.

Wissema, J. G., (2009). Towards the Third Generation University. Managing the University in Transition. Cheltenham: Edward Elgar Publishing.

Wright Mills, C. (1999). La imaginación sociológica. Madrid: Fondo de Cultura Económica.

\section{BIOGRAPHICAL NOTE}

Antonio Ariño is Senior Professor of Sociology at the Faculty of Social Sciences at the Universitat de València. He holds a Bachelor's degree in Geography and History and a PhD in Sociology from the Universitat de València. His research focuses on the sociology of culture, welfare policies, and sociological theory. He was awarded the National Research Prize for his work entitled «La ciudad ritual» (Anthropos). Dr. Ariño has held numerous positions: Director of the Department of Sociology and Social Anthropology (1997-2003), Vice-rector for Academic Studies and Organisation (2003-1998), Vice-rector for European Convergence and Quality (2006-2010), Vice-rector for Planning and Equality (2010-2012) and, since 2012, he has held the position of Vice-rector for Culture and Equality at the Universitat de València. 


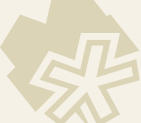

